\title{
ARE OPINION LEADERS MORE SATISFIED? \\ RESULTS OF A SEM MODEL ABOUT THE RELATIONSHIP BETWEEN OPINION \\ LEADERSHIP AND ONLINE CUSTOMER SATISFACTION
}

\author{
Akos Nagy \\ Assistant Lecturer, Faculty of Business and Economics, University of Pécs, Hungary \\ Email: nagya@ktk.pte.hu \\ Ildikó Kemény \\ Assistant Research Fellow, Corvinus University of Budapest, Hungary \\ Krisztián Szücs \\ Associate Professor, Faculty of Business and Economics, University of Pécs, Hungary \\ Judit Simon \\ Professor, Corvinus University of Budapest \\ Viktor Kiss \\ Assistant Lecturer, Faculty of Business and Economics, University of Pécs, Hungary
}

More and more research is dedicated to address the phenomenon of online word-of-mouth (WOM). Concerning electronic WOM, three major underlying motives can be differentiated: opinion seeking, opinion giving and opinion passing (Flynn et al. 1996, Sun et al. 2006). The main aim of the research is to analyse the relationship between these three dimensions and the level of customer satisfaction. The research is based on a representative sample of 1000 respondents living in Hungary. According to the hypothesized Structural Equation Model (SEM), we can conclude that online opinion seeking behaviour has a significant positive impact on levels of customer satisfaction, as well as on opinion giving and opinion passing. This implies that opinion leaders not just share, but also collect enormous amounts of information about products and services and raise their expectations according to feedback. By doing so, their prior expectations are in relation to the true customer value of online stores and products. This means that customer satisfaction - measured using the disconfirmation paradigm - will reach a higher level, so it is advisory for online retailers to encourage customers to give feedback, write reviews, because it will affect the customer satisfaction level in a positive manner.

KEYWORDS: online word-of-mouth, customer satisfaction, opinion seeking, opinion leadership

JEL CODE: M31 


\section{INTRODUCTION}

The world became 'digital' around the middle of the 90's (Szabó - Hámori 2006: 66). Nowadays information on the Internet can support the pre-purchase decision or even the entire purchase process. In Hungary, $25 \%$ of the total population have acquired goods or services online in the previous year (Eurostat 2013) and the percentage of online shoppers is increasing from year to year. The indicator of those who already made an online purchase in the age group of 18-49 has seen an increase from $74 \%$ to $76 \%$ in 2012. Additionally the proportion of online shoppers who purchase something at least once a month on the Internet, has rose from $25 \%$ to $28 \%$ (GFK 2014). Accordingly one of today's most important research fields is online customer satisfaction. An enormous amount of studies highlight the fact that the retention of customers has a lower costs compared to the acquisition of new ones, therefore increasing satisfaction level of current customers contributes to the profit margin and serves as a key to success in the long term (Carlson - O'Cass 2010; Christodoulides - Michaelidou 2011; Teimouri et al. 2012). In this context word-of-mouth (WOM) communication addresses an important arising question: how does information from other consumers/users contribute to the satisfaction level with products and services? The significance of WOM for corporate marketing activities has long been recognized and it became more noticeable in recent years. According to the results of a questionnaire survey of 10000 consumers conducted every three years by the Nomura Research Institute (NRI) the importance of word-of-mouth has been growing, consumers place greater trust in the evaluations of actual product users, rather than the official information published by the company, although they have recently been facing difficulties in "choosing useful information" because sometimes companies easily manipulate opinions and use fake profiles and recommendations (Murakami - Natori 2013). An extensive amount of research has been dedicated to the analysis of the influence of interpersonal communication and personal influence on consumer decisions since the 1950s (Arndt 1967). Moreover it is confirmed that word-of-mouth has a significant impact on consumer expectations (Anderson - Salisbury 2003), pre-usage attitudes (Herr et al. 1991) and shapes post purchase product and service perceptions (Bone 1995) especially in the case of consumer durables and sensitive services. Some studies highlight that WOM is much more effective than print ads, personal selling or radio spots (Engel et al. 1969). However, Van den Bulte and Lilien (2001) found that these studies overestimate its effectiveness. According to Chu and Kim (2011), online word-of-mouth can be structured into three underlying behavioural dimensions: opinion seeking, opinion giving and opinion passing. A large amount of research has addressed the relationship of satisfaction to word-of-mouth (e.g. Anderson 1998), however the opposite direction and essential personal characteristics could be examined as well. We follow this perspective and aim to observe the relationship of the fundamental behavioural dimensions to satisfaction. In this manner our main research question is the following: what effect does opinion seeking, opinion giving and opinion passing behaviour have on perceived online customer satisfaction level? 


\section{ONLINE WORD-OF-MOUTH RESEARCH}

Through internet capable devices opinions, reviews and referrals are diffused at a higher level and speed than ever before. Electronic word-of-mouth (eWOM), is defined as "any positive or negative statement made by potential, actual, or former customers about a product or company, which is made available to a multitude of people and institutions via the Internet" (Hennig-Thurau et al. 2004: 39). This definition is an extension of Arndt's (1967) original version where word-of-mouth is characterized as oral, person-to-person communication about a brand, product, or a service between a receiver and a communicator whom the receiver perceives as non-commercial. Due to computer mediated communication characteristics eWOM is different from its traditional form in many ways. Unlike traditional WOM, where sharing of information is between small groups of individuals in synchronous mode (Steffes - Burgee 2009), online word-of-mouth communications involve multi-way exchanges of information in asynchronous mode (Hung - Li 2007). Because information does not need to be exchanged at the same time, eWOM communications are more persistent and accessible. The text-based information is usually archived and can be made available for long period of time (Hennig-Thurau et al. 2004). Furthermore, this allows measuring and observing electronic word-ofmouth. In traditional face-to-face conversations information is presented in private talk, but online partners do not need to be there at the same time and so opinions are spread to unknown individuals and groups (Karakaya - Barnes 2010). Therefore, widened networked communications can facilitate information exchange among people of various backgrounds (Van Alstyne - Brynjolfsson 2005). Traditional WOM originates from a sender who is known to the receiver of the information, and so the credibility of both the communicator and the message is recognized by the receiver. In the case of online WOM - because most of the time no direct face-to-face communications appear - opinions and referrals are unsolicited and will only be evaluated if it attracts the attention of prospective adopters and they find them (Park - Kim 2008).

According to Cheung and Thadani (2012), theoretical online word-of-mouth research can be divided into two realms: market-level analyses and individual-level analyses. In the case of market-level analyses, conclusions are drawn up from market indicators such as sales volume, objective panel data (i.e. website traffic, the rate and the valence of consumer reviews) (Zhu - Zhang 2010). On the other hand, individual-level analyses postulate eWOM as a process of personal influence, in which communications between a communicator (sender) and a receiver can influence consumer purchase decisions (Park - Kim 2008). In this respect, studies focus on the understanding of antecedents and consequences that determine WOM communications, along three research streams. The first stream concentrates on the reasons why consumers actively spread the word about their experiences regarding certain services or products. Among major factors satisfaction or dissatisfaction (Bowman Narayandas 2001), company commitment (Dick - Basu 1994), relationship duration (Wangenheim Bayon 2004) and product novelty (Bone 1992) can be mentioned. The second stream aims at better understanding information-seeking behaviour, especially the circumstances under which consumers 
rely on WOM communications more than on other sources in the decision making process. Consumers are more likely to seek the opinions of others if they have no or little expertise in a product category (Fuse et al. 1984), perceive a high risk in decision making (Bansal - Voyer 2000) or their involvement level is high (Beatty - Smith 1987). Studies in the third stream examine why certain personal sources of information exert more influence than others. Important factors are source expertise (Bansal Voyer 2000), tie strength and demographic similarity (Brown - Reingen 1987). An also significant, but presently not addressed issue is source expertise, which is a mixture of competence, authority and know-how. It has an impact on trust, and along with argument quality, it has a positive effect on brand attitudes (Chu - Kamal 2008). Hence in certain fields accepted and sought out sources, reviews, tests, rating sites (e.g. tripadvisor.com) or market mavens (Gladwell 2007) exist, whose opinion people accept easily and prefer to adopt their views.

\section{THE CONSTRUCT OF OPINION LEADERSHIP}

When confronting unusual circumstances, unfamiliar issues and/or challenging decisions, individuals in search of pertinent information frequently turn to others within their social spheres who they think are better informed on the subject. These more knowledgeable people who are able to provide product specific information are called opinion leaders. Opinion leaders are persuasive due to their involvement, expertise and experience in a given product category (Myers - Robertson 1972). Another source of personal influence is market mavens, but they are different compared to opinion leaders, because their influence stems not from product category expertise, but from general knowledge or market expertise (Feick - Price 1987). The issue of opinion leadership has been of interest to marketing managers and researchers for a long time, because opinion leaders play an important role in successful marketing campaigns and the concept makes a key contribution to models of consumer decision making (Engel et al. 1990; Rogers 2003). A more affluent picture of eWOM communication can be obtained by an exploration of the opinion leadership process, especially the associated three behavioural motives: opinion seeking, opinion giving and opinion passing (Chu - Kim 2011). Consumers with a high level of opinion seeking behaviour tend to search for information and advice from others when making a purchase decision (Flynn et al. 1996). Conversely, individuals with a high level of opinion giving behaviour, known as opinion leaders, may exert great influence on others' attitudes and behaviours (Feick - Price 1987). Opinion leaders are defined as individuals who transmit information about a topic to other people, in terms of the extent to which information is sought by those people (King - Summer 1970). Many opinion leaders may also be opinion seekers because they desire more knowledge or expertise, partly due to their interest in a specific topic or product. Even though, information seekers are not necessarily opinion leaders (Arndt 1967; Feick - Price 1987; Lazarsfeld et al. 1984). Opinion seeking is essential to WOM communication because it facilitates information diffusion in the interpersonal communication process (Reynolds - Darden 1971). Opinion leaders cannot exist without opinion seekers, and vice versa. Regarding online WOM, the Internet not 
only provides opinion leaders with efficient ways to disseminate information, but also greatly facilitates information searching for opinion seekers (Sun et al. 2006). In cyberspace, with the advent of web 2.0 a dynamic and interactive eWOM is enabled, where a single person can take on multiple roles of opinion provider, seeker and transmitter. As the line between the roles becomes blurred, online consumers' search for brand information, content creation and willingness to share content with others (Chu - Kim 2011). Sun et al. (2006) highlight that online forwarding/passing is an important and yet overlooked (Norman - Russel 2006) behavioural consequence of eWOM and it accelerates the flow of information. Opinion passing behaviour is more likely to occur in an online social context, as the unique characteristics of the Internet can facilitate multidirectional communication, and with a few clicks of the mouse, consumers can 'spread the word' on a global scale (Dellarocas 2003; Chu - Kim 2011).

\section{THE IMPORTANCE OF INFORMATION IN CUSTOMER SATISFACTION}

The tendency to purchase online is shaped by many factors, among them the most important personal characteristics are attitude to technology, "network lifestyle", time spent online, internet usage experience, technological skills and optimism (Bellman et al. 1999; Modahl 2000; Novak et al. 2000; Parasuraman 2000; Wolfinbarger - Gilly 2002). In respect of demographics, online consumers are characterized by higher income, career orientation, convenience and time saving desire (Lohse Bellman 2000; Parasuraman 2000; Wolfinbarger - Gilly 2002). Beside consumer habits, the so called situational effects should not be ignored either. Product and service characteristics, consumer's mood, whether the purchase is goal-oriented, purposeful, and the fact that planned or hedonic values play a more important role in the decision (Wolfinbarger - Gilly 2002).

Satisfaction measurement methodologies can be divided into subjective and objective methods. Objective indicators such as market share, churn rate, repurchase rate etc., and are calculated indirectly, while subjective methods are based on customer perceptions (Hofmeister-Tóth et al. 2002; Kenesei - Kolos 2007). The disconfirmation paradigm has a central role among customer satisfaction measurement techniques, where satisfaction or dissatisfaction is a result of the relationship between expectations and performance (Hofmeister-Tóth et al. 2002). If we accept that satisfaction is about the entire performance of a provider, then quality is the antecedent of satisfaction (Johnson - Fronell 1991). Therefore satisfaction can be measured based on the expected and observed value of quality dimensions. Expectations are built up during earlier usage, communication phases as well as during the shopping experience and serve as a measure for performance. The equality of expectations and performance means confirmation, while over performance results in positive and under performance in negative disconfirmation which lead to affective reactions such as satisfaction or dissatisfaction (Oliver 1980; Szymanski - Henard 2001). It can be concluded that many factors affect customer expectations which are a basis for comparison. Along with needs and wants, previous experiences and quality assessment are among the most notable internal customer information. Among external 
information sources interpersonal conversations, word-of-mouth or corporate marketing activities can be highlighted (Hill 1986).

Many researchers agree that the evaluation of the quality of online stores is not limited to the transaction itself, but includes the entire range of provided electronic services (Montoya - Weiss et al. 2000; Wolfinbarger - Gilly 2002; 2003; Zeithaml et al. 2002; Minocha et al. 2005, Bauer et al. 2005). These include all interactive services, which are conveyed via information-communication technologies (Sousa - Voss 2006). Accordingly, quality assessment should take into account the preand post-service aspects, such as the information gathering process, transaction accomplishment, customer service, or even refunds and problem management.

Minocha et al. (2005, 5-6) describe the online shopping experience process with six steps:

1. Expectation setting: the customer draws upon a number of social, organisational and individual influences from which he will create a personal benchmark of service quality expectations influenced by his motivations, needs, benefits and costs of using e-commerce, recommendations, word-of-mouth, advertising, and so on. These influences play a vital role in his decision about which website to visit and whether or not to make a purchase on a certain website.

2. Pre-purchase interactions: the customer chooses a website, searches for a products or services and makes a decision about whether or not to make a purchase, which is based on the usability of the homepage and other webpages of this site, information provided about the product or service, the price, the credibility of the website, the delivery mechanisms and refunds policy, etc.

3. E-purchase interaction: the customer selects the product or service and completes the transaction; this usually involves entering personal details, billing and delivery information, and credit card details.

4. Post-purchase interactions: involves tracking the order and receiving the delivery of products / services, the customer may need to query an order, complain about the state of the delivery, or question his credit card handling, and he is likely to contact the organisation at touch points other than the website.

5. Product/service consumption: if the customer is also the consumer, he will consume the products / services.

6. Post-total customer experience (TCE) evaluation: the customer will review experiences of conducting business with the e-commerce environment. During this stage, the customer compares the overall experience with the benchmark of expectations set during the first stage, and assesses whether he has received value from his experience. Unpleasant or unsatisfactory experiences across any of these stages and / or during the consumption stage may render a negative TCE, despite the e-commerce website being usable. 
Accordingly, the future behaviour of customers (satisfaction, repurchase, referral, loyalty, etc.) is influenced by factors before, during and after the buying procedure. One of these factors could be the opinion leadership characteristics in relation to the motives of the given customer.

\section{RESEARCH MODEL AND CORE ASSUMPTIONS}

The research examines online word-of-mouth tendencies, especially the relationship between opinion seeking, opinion giving, opinion passing behaviour and customer satisfaction with online stores. We follow a general approach in the assessment of online word-of-mouth and do not restrict it to any kind of platform or major type. Our main aim is the identification of the relationship between the previously mentioned behavioural dimensions, hence major sources (test/review sites, or experts) of information are not highlighted - the focus is on computer mediated communication between peers in the network and their personal characteristics.

Based on the previous literature review and considerations we draw up the following and hypotheses:

H1: Online opinion seeking behaviour has a positive effect on opinion adoption.

As Cheung et al. (2009) state, considerable research has already demonstrated the relationship between information credibility and adoption. McKnight and Kacmar (2006) demonstrated the positive effect of the receiver's perceived information credibility on the willingness to accept the information of a website. We can assume that if a person is making a bigger effort in seeking information on the Internet, the amount - and so the adoption of information (opinions, recommendations, reviews, etc.) will reach a higher level.

H2: Opinion adoption has a positive effect on customer satisfaction.

We can conclude that the gathered opinions about a certain product or service/web-store contain useful information because of adaption. It is also obvious that these information shape customers' expectations and help to evaluate whether to take the next step of the decision making process or not. Based on the disconfirmation paradigm customer satisfaction or dissatisfaction is a result of the relationship between expectations and performance (Hofmeister-Tóth et al. 2002). Hence if the gathered information helps to evoke customer expectations close to the real performance and avoid mistaken decisions it results in greater satisfaction.

H3: Online opinion seeking has a positive effect on online opinion giving.

H4: Online opinion seeking has a positive effect on online opinion passing.

H5: Online opinion giving has a positive effect on online opinion passing. 
As stated before, opinion leaders cannot exist without opinion seekers, and vice versa. Also, with the advent of the Internet, opinion passing became an important part of the process as well. Information seekers are not necessarily opinion leaders, but many opinion leaders may also be opinion seekers because they desire more knowledge or expertise and the Internet provides several ways to disseminate information and enables advanced information search as well (Sun et al. 2006). Due to the possibility of acquiring an enormous amount of information, it is assumed that there is a positive relation among the different aspects of the online opinion leadership construct.

H6: Online opinion giving has a positive effect on customer satisfaction.

H7: Online opinion passing has a positive effect on customer satisfaction.

If hypotheses 4 and 5 are supported, we can assume that online opinion giving and passing behaviour is positively related to customer satisfaction. Information collected and spread through the Internet can help people in selecting the ideal alternatives of products and services. It can also help those who already have personal experience from usage or transactions and want to share their opinions. It could be argued that if negative experiences occur, customers are willing to share it with others or pass along information to those who they think might be interested in the same products and services. Hence customer satisfaction is not necessarily in positive relation to the opinion passing behaviour of customers.

Drawing from the measures of online word-of-mouth used in previous studies (Flynn et al. 1996; Sun et al. 2006), the engagement in eWOM was operationalised with three specific behaviours: opinion seeking, opinion giving and opinion passing. Specifically, Flynn et al.'s (1996) opinion seeking and opinion leadership scales were adopted to the online environment and to the research design. Opinionpassing behaviour was measured by adopting Sun et al.'s (2006) online forwarding scale. The number of items was reduced in order to meet the expectations of online questionnaires. Online satisfaction was measured using Chang et al. (2009) scale and opinion adoption was operationalised based on the review/recommendation adaption scale used by Cheung et al. (2009). The items used in the questionnaire are listed in Table 1, and the hypothesized relationships between them are shown in Figure 1.

Table 1. Research scales

\begin{tabular}{|c|l|}
\hline Factors & Indicators \\
\hline & $\begin{array}{l}\text { 1. I agree with the online review/recommendation. } \\
\text { 2. Information from the online review/recommendation contributed to my } \\
\text { knowledge of discussed product/service. }\end{array}$ \\
$\begin{array}{c}\text { eWOM review / recommendation } \\
\text { adoption: (Cheung et. al 2009) (1-7 } \\
\text { Likert scale) (OPADOPT) }\end{array}$ & $\begin{array}{l}\text { 3. The online review/recommendation made it easier for me to make purchase } \\
\text { 4. The online review/recommendation has enhanced my effectiveness in making } \\
\text { purchase decision. } \\
\text { 5. The online review/recommendation motivated me to make purchase action. }\end{array}$ \\
\hline Customer satisfaction: Chang et al. & 1. I am satisfied with my decision to purchase from this Web site. \\
\hline
\end{tabular}




\begin{tabular}{|c|c|}
\hline 2009 (1-7 Likert scale) (SAT) & $\begin{array}{l}\text { 2. If I had to purchase again, I would feel differently about buying from this } \\
\text { website. } \\
\text { 3. My choice to purchase from this website was a wise one. }\end{array}$ \\
\hline $\begin{array}{l}\text { Online opinion seeking: based on } \\
\text { Flynn et al. (1996) adapted by Sun et } \\
\text { al. (2006) and Chu \& Kim (2011) (1-7 } \\
\text { Likert scale) (OPSEEK) }\end{array}$ & $\begin{array}{l}\text { 1. When I consider new products, I ask others on the internet for advice. } \\
\text { 2. I like to get others opinions on the internet before I buy new products. } \\
\text { 3. I feel more comfortable choosing products when I have gotten my others' } \\
\text { opinions on them. }\end{array}$ \\
\hline $\begin{array}{l}\text { Online opinion giving: } \\
\text { based on Flynn et al. (1996) adapted } \\
\text { by Sun et al. (2006) and Chu \& Kim } \\
\text { (2011) (1-7 Likert scale) (OPGIV) }\end{array}$ & $\begin{array}{l}\text { 1. I often persuade others on the internet to buy products that I like. } \\
\text { 2. My contacts on the internet pick their products based on what I have told them. } \\
\text { 3. On the internet, I often influence others' opinions about products. }\end{array}$ \\
\hline $\begin{array}{l}\text { Online opinion passing: } \\
\text { Based on Flynn et al. (1996) adapted } \\
\text { by Sun et al. (2006) and Chu \& Kim } \\
\text { (2011) (1-7 Likert scale) (OPPASS) }\end{array}$ & $\begin{array}{l}\text { 1. When I receive product related information or opinion from a friend, I will pass } \\
\text { it along to others on the internet. } \\
\text { 2. On the internet, I like to pass along interesting information about products from } \\
\text { one group of my contacts to another. } \\
\text { 3. I tend to pass along others' positive reviews of products to other contacts on the } \\
\text { internet. }\end{array}$ \\
\hline
\end{tabular}

\section{Source: authors}

Figure 1. The proposed initial model

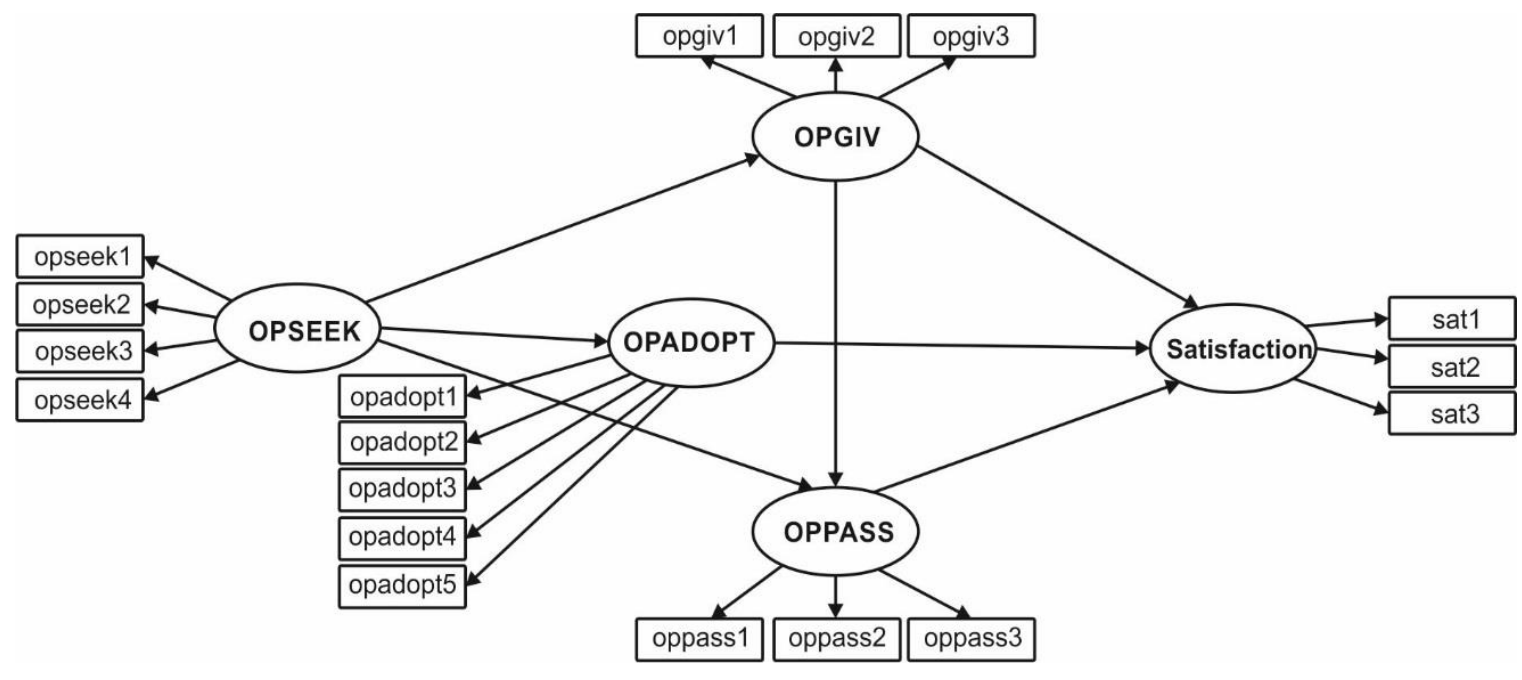

Source: authors

\section{RESEARCH RESULTS}

In order to verify the proposed model and to draw up electronic word-of-mouth tendencies we conducted an online survey in Hungary. Respondents were selected out of an online panel and only those were accepted who have purchased a product or service online in the past three months. The sample is representative of the Hungarian population with respect to gender, age and type of settlement. Descriptive statistics of the responses to the questions in the instrument are shown in Table 2.

In model development and assessment, confirmatory factor analysis (CFA) and structural equation modelling (SEM) were used.

Table 2: Demographic results

\begin{tabular}{|l|c|}
\hline GENDER & $\mathbf{N}=\mathbf{1 0 0 0}$ person \\
\hline Male & $43.50 \%$ \\
\hline
\end{tabular}

\begin{tabular}{|l|c|}
\hline TYPE OF SETTLEMENT & $\mathbf{N}=\mathbf{1 0 0 0}$ person \\
\hline Capital & $30.60 \%$ \\
\hline
\end{tabular}




\begin{tabular}{|c|c|c|c|}
\hline Female & $56.50 \%$ & County seat & $23.70 \%$ \\
\hline \multicolumn{2}{|l|}{ AGE GROUP } & Other big city & $13.70 \%$ \\
\hline $18-29$ & $9.40 \%$ & Village & $31.60 \%$ \\
\hline $30-39$ & $26.40 \%$ & Other & $0.40 \%$ \\
\hline $40-49$ & $20.10 \%$ & \multicolumn{2}{|l|}{ FAMILY STATUS } \\
\hline $50-59$ & $19.90 \%$ & Single & $13.40 \%$ \\
\hline $59+$ & $23.70 \%$ & In a relationship & $21.80 \%$ \\
\hline AVERAGE AGE & 46.83 year & Married & $45.10 \%$ \\
\hline \multicolumn{2}{|l|}{ EDUCATION } & Divorced & $8.80 \%$ \\
\hline Primary school & $0.60 \%$ & Widow & $3.60 \%$ \\
\hline Secondary school & $6.40 \%$ & In a civil partnership & $7.30 \%$ \\
\hline High School & $36.30 \%$ & \multicolumn{2}{|l|}{ HOUSEHOLD TYPE } \\
\hline College & $28.70 \%$ & I live with my parents & $9.70 \%$ \\
\hline University & $26.70 \%$ & I live with my parents and grandparents & $1.10 \%$ \\
\hline \multicolumn{2}{|l|}{ NET MONTHLY INCOME } & I live with my friends / shared apartment & $1.40 \%$ \\
\hline $\begin{array}{l}\text { Our monthly income is not enough to buy the } \\
\text { basic goods. }\end{array}$ & $5.30 \%$ & I live alone & $14.00 \%$ \\
\hline $\begin{array}{l}\text { We could buy the basic goods, but we cannot buy } \\
\text { any extras. }\end{array}$ & $26.90 \%$ & I live with my partner without a child & $30.90 \%$ \\
\hline $\begin{array}{l}\text { We could buy the basic goods, and we can buy } \\
\text { some extras. }\end{array}$ & $54.40 \%$ & I live with my partner with a child & $33.70 \%$ \\
\hline We can buy everything easily what we need. & $13.40 \%$ & I live without a partner but with a child & $6.70 \%$ \\
\hline AVERAGE NET INCOME & $120654 \mathrm{Ft}$ & Other & $2.50 \%$ \\
\hline
\end{tabular}

Source: author

According to our results, $36.7 \%$ of the respondents are looking for information in the first stage of the online purchase process, when wants and needs arise. In the initial information search period the level drops a bit by $0.7 \%$ to $36 \%$, but it rises again up to $38.3 \%$ when customers have to compare alternatives. Post purchase evaluations appear only at $8.1 \%$ of the respondents and $14.1 \%$ marked that they are not looking for information from others during the purchase decision process. Reviews, recommendations from others stem from different sources. More than $40 \%$ of the respondents marked that they get opinions on the own website of the brand / company or web shop. However, the most influential information stems from review sites (mean: 5.59).

Internal consistency of the used scales in the proposed model is acceptable: the Cronbach-alphas are higher than 0.7 (Nunnaly - Bernstein 1994), and the composite reliability values (CR) are also higher than 0.7 . The construct and discriminant validity of the scales are also sufficient, the AVE-s are higher than 0.5, and square roots of AVE-s are higher than the correlations between the constructs (Fornell Larcker 1981) (see Table 3). For the analysis of the reliability of the items, we used confirmatory factor analysis. Based on our results we could conclude that the items describe the supposed constructs well: with one exception all of the items have a standardized regression weight higher than 0,7 . If this item (OPSEEK1) were deleted, the goodness of fit of the model would not increase, thus we can keep this item in our model (see Table 4).

Table 3. Reliability and correlations for the construct

\begin{tabular}{|l|c|c|c|c|c|c|c|c|}
\hline & $\begin{array}{c}\text { CR > 0.7 } \\
\text { (Hair et al } \\
2010)\end{array}$ & $\begin{array}{c}\text { AVE > 0.5 } \\
\text { (Fornell - Larcker } \\
\text { 1981) }\end{array}$ & $\begin{array}{c}\text { Cronbach > 0.7 } \\
\text { (Hair et al 2010) }\end{array}$ & OPADOPT & OPSEEK & SAT & OPPASS & OPGIV \\
\hline OPADOPT & 0.900 & 0.644 & 0.900 & 0.803 & & & & \\
\hline OPSEEK & 0.913 & 0.727 & 0.909 & 0.612 & 0.853 & & & \\
\hline
\end{tabular}




\begin{tabular}{|c|c|c|c|c|c|c|c|c|}
\hline SAT & 0.949 & 0.861 & 0.948 & 0.271 & 0.130 & 0.928 & & \\
\hline OPPASS & 0.909 & 0.769 & 0.907 & 0.425 & 0.410 & 0.017 & 0.877 & \\
\hline OPGIV & 0.897 & 0.745 & 0.897 & 0.386 & 0.429 & -0.034 & 0.860 & 0.863 \\
\hline & & \multicolumn{2}{|c|}{ Item } & \multicolumn{5}{|c|}{ Std. regr. weight $(>0.7)$} \\
\hline \multirow{4}{*}{\multicolumn{2}{|c|}{ Opinion seeking }} & & & \multicolumn{5}{|c|}{0.687} \\
\hline & & \multicolumn{2}{|c|}{ OPSEEK2 } & \multicolumn{5}{|c|}{0.823} \\
\hline & & \multicolumn{2}{|c|}{ OPSEEK 3} & \multicolumn{5}{|c|}{0.952} \\
\hline & & \multicolumn{2}{|c|}{ OPSEEK 4} & \multicolumn{5}{|c|}{0.924} \\
\hline \multirow{5}{*}{\multicolumn{2}{|c|}{ Opinion adoption }} & \multicolumn{2}{|c|}{ OPADOPT1 } & \multicolumn{5}{|c|}{0.718} \\
\hline & & \multicolumn{2}{|c|}{ OPADOPT2 } & \multicolumn{5}{|c|}{0.757} \\
\hline & & \multicolumn{2}{|c|}{ OPADOPT3 } & \multicolumn{5}{|c|}{0.876} \\
\hline & & \multicolumn{2}{|c|}{ OPADOPT4 } & \multicolumn{5}{|c|}{0.835} \\
\hline & & \multicolumn{2}{|c|}{ OPADOPT5 } & \multicolumn{5}{|c|}{0.818} \\
\hline \multirow{3}{*}{\multicolumn{2}{|c|}{ Opinion giving }} & \multicolumn{2}{|c|}{ OPGIV1 } & \multicolumn{5}{|c|}{0.835} \\
\hline & & \multicolumn{2}{|c|}{ OPGIV2 } & \multicolumn{5}{|c|}{0.856} \\
\hline & & \multicolumn{2}{|c|}{ OPGIV3 } & \multicolumn{5}{|c|}{0.897} \\
\hline \multirow{3}{*}{\multicolumn{2}{|c|}{ Opinion passing }} & \multicolumn{2}{|c|}{ OPPASS1 } & \multicolumn{5}{|c|}{0.827} \\
\hline & & \multicolumn{2}{|c|}{ OPPASS2 } & \multicolumn{5}{|c|}{0.892} \\
\hline & & \multicolumn{2}{|c|}{ OPPASS3 } & & & 0.91 & & \\
\hline & & & & & & 0.939 & & \\
\hline & & & & & & 0.877 & & \\
\hline & & & & & & 0.965 & & \\
\hline
\end{tabular}

Source: authors

The fit indexes of the assumed model were very good: root mean square of approximation (RMSEA) $=$ 0.06; Trucker-Lewis index $(\mathrm{TLI})=0.96$; comparative fit index $(\mathrm{CFI})=0.97$; normed fit index $(\mathrm{NFI})=$ 0.97 (see Table 4).

Table 4. Goodness of Model Fit Indices

\begin{tabular}{|l|l|l|}
\hline RMSEA & $\leq 0.06$ (Hu and Bentler 1999); $\leq 0.07$ if CFI $\geq 0.92$ (Hair et al., 2010) & 0.06 \\
\hline CMIN/d.f & $<5$ (Marsh \& Hocevar 1985; Carmines \& McIver 1981); $\leq 3$ (Bentler 1990) & 4.02 \\
\hline NFI & $\geq 0.90$ (Hair et al. 1992) & 0.97 \\
\hline TLI & $\geq 0.90$ (Homburg and Baumgartner 1996) & 0.96 \\
\hline CFI & $\geq 0.90$ (Homburg and Baumgartner 1996) & 0.97 \\
\hline
\end{tabular}

** CMIN/d.f. ( $\chi 2 /$ degree of freedom); RMSEA = Root Mean Square Error of Approximation; NFI = Normed Fit Index; TLI

$=$ Tucker-Lewis Index; $C F I=$ Comparative Fit Index

Source: authors

The explained variance of the used constructs are acceptable $\left(\mathrm{R}^{2}{ }_{\text {OPPASS }}=0.741, \mathrm{R}^{2}\right.$ OPADOPT$=0.376$, $\mathrm{R}^{2}$ OPGIV $=0.189, \mathrm{R}_{\mathrm{SAT}}^{2}=0.101$ ). The reason for satisfactions' lowest explained variance could be that the typical antecedents of satisfaction - as perceived quality or perceived value - were not used in this model, the focus was only on some personal characteristics and consumer attitudes (Figure 2). 
Figure 2. The model results (path coefficients)

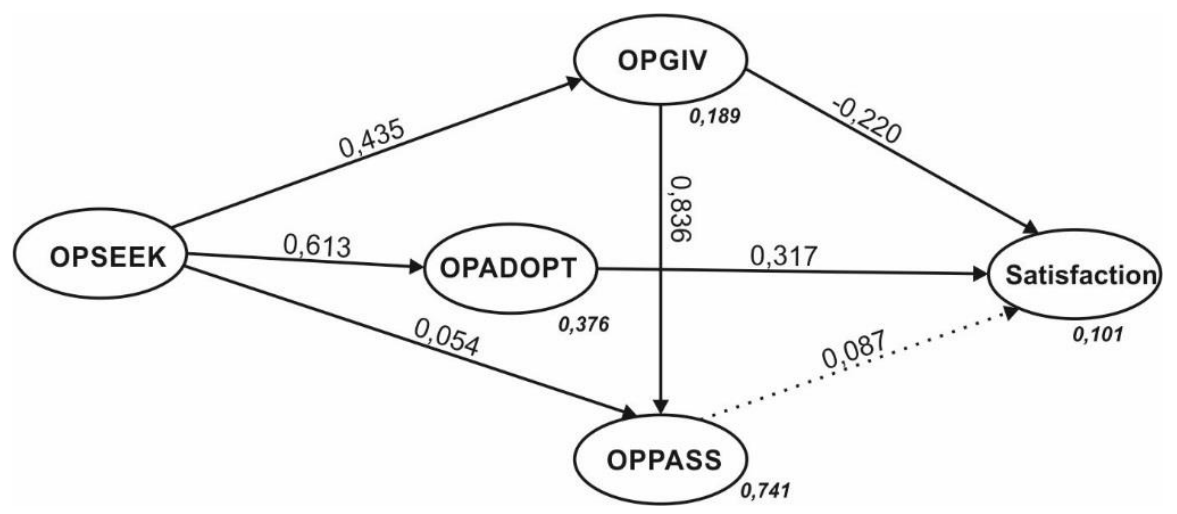

Source: author

The main findings are presented in Table 5. The hypotheses regarding links between constructs connected to the major behaviour types of WOM were supported. Only one hypothesis dealing with satisfaction as an output was supported. Based on these results, opinion adopting behaviour has a positive significant effect on satisfaction. Opinion giving also has a significant effect on satisfaction, but is it not positive as we assumed. Opinion passing has no significant effect on satisfaction.

Table 5. Summary of the results

\begin{tabular}{|l|c|c|c|}
\hline & $\begin{array}{c}\text { Standardized Regression } \\
\text { Weights }\end{array}$ & t-value & Hypothesis supported \\
\hline H1 (+) OPSEEK --> OPADOPT & 0.613 & $* * *$ & Yes \\
\hline H2 (+) OPADOPT --> SAT & 0.317 & $* * *$ & Yes \\
\hline H3 (+) OPSEEK --> OPAGIV & 0.435 & $* * *$ & Yes \\
\hline H4 (+) OPSEEK --> OPPASS & 0.054 & 0.026 & Yes \\
\hline H5 (+) OPGIV --> OPPASS & 0.836 & $* * *$ & Yes \\
\hline H6 (+) OPGIV --> SAT & -0.22 & 0.006 & No \\
\hline H7 (+) OPPASS --> SAT & 0.087 & 0.268 & No \\
\hline
\end{tabular}

Source: authors

\section{CONCLUSIONS AND MANAGERIAL IMPLICATIONS}

An enormous amount of research has been dedicated to the issue of assessing customers' satisfaction level. It has been widely recognized that satisfaction is among the major factors which affect customers' future behaviour. It has a tenacious relationship with quality and according to the theory it is shaped by prior expectations. These are dependent on various personal and situational factors. Among them this study focused on a certain issue: word-of-mouth. The relationship between customer satisfaction and WOM is regularly analysed in a way where the major question is about WOM intent. Precisely, what are the major factors which motivate a customer who has certain experiences with a 
product or company to share his or her opinion with others? In our research we followed a different aspect: how is customer satisfaction shaped by a customers' certain behavioural characteristics which are linked to the different dimensions of opinion leadership? With the advent of the internet, information about products and services reaches a higher and higher level every day. Customers have the opportunity to seek and give opinions about their purchase and consumption experiences easier than ever before. Due to this it is an eligible question: Is someone who is highly involved in searching for information will be more satisfied or not? We could expect that someone who is trying to collect others' opinion will be more satisfied with a given purchase decision because his or her expectations have been raised and directed by the available information. An equally important question is that do those who provide this information are sharing thoughts which can be used in a purchase decision or not? According to traditional word-of-mouth literature, opinion leaders cannot exist without opinion seekers and vice versa. Those who are willing to share information with others have to bear in mind that their opinion will be only listened to if it is reliable and relevant. In order to meet these expectations we can await that they will be trying to seek information as well. Opinion giving would also be irrelevant if no one would listen to it. On the other hand, online word-of-mouth has a third dimension which is opinion passing, i.e. forwarding information to others who might have not received it yet. It is also hypothesised that opinion passing is positively related to the other behavioural dimensions of opinion leadership. Following these considerations it can be assumed that those who are gathering and sharing information with others on the internet will be more satisfied with a certain purchase decision because their expectations will be raised according to the real product or service value. In our model we have synthetized these questions and could approve many of the hypothesised relationships. It could be proven that the three different behavioural dimensions of online opinion leadership are related. A higher level of opinion seeking behaviour will result in higher opinion giving, and - even though the path coefficient is very low - it will positively affect opinion passing as well. Opinion giving is positively related to opinion passing which means that those who are willing to give product recommendations and reviews are willing to share information stemming from other sources as well. They are not just taking an active role in the procedure but are also motivated to pass along information. The major question about the relationship between opinion seeking, giving, sharing and customer satisfaction cannot be answered in a simple way. While we can conclude that opinion seeking behaviour has a positive effect on customer satisfaction mediated by opinion adoption; satisfaction is negatively related to opinion giving. One of the reasons behind this relationship could be that those who are involved in sharing their personal experiences are more critical than others. Their expectations could be guided by their personal attitude of continuously assessing the purchase period in order to find positive and negative matters. Opinion giving is effort consuming and an active behaviour, it needs time and issues which could be interesting to others. While opinion seekers adopt information and their expectations are shaped by the adopted opinions, opinion givers have to pay attention to every detail. Consequently their customer satisfaction level is not just a result of 
previously shaped expectations and the habituation of being 'satisfied', they also put effort into assessing every purchase decision. An additional reason could be that opinion givers are involved in searching for information, comparing many opinions and might have a wider view about the different characteristics. Due to more assessment dimensions of a given product or service, their satisfaction level will be more varied. However in order to find exact reasons, further research should be initiated. Nevertheless we can conclude that opinion seeking has a positive effect on the behavioural intention of giving and passing along product information and two of the behavioural dimensions of opinion leadership have a significant effect on prior expectations and customer satisfaction level. It is highly recommended for companies to make a platform for online word-of-mouth available on their website and encourage customers to share thoughts with each other about products and services in order to reach higher level of customer satisfaction.

\section{References}

Anderson, E. (1998): Customer Satisfaction and Word of Mouth. Journal of Service Research 1(1): 517.

Anderson, E. W. - Saisbury, L. C. (2003): The formation of market level expectations and its covariates. Journal of Consumer Research 30: 115-124.

Arndt, J. (1967): Word of Mouth Advertising: A Review of the Literature. New York: Advertising Research Foundation.

Bansal, H. S. - Voyer, P. A. (2000): World-of-mouth processes within a services purchase decision context. Journal of Service Research 3(2): 166-177.

Bauer, H. H. - Falk, T. - Hammerschmidt, M. (2006): eTransQual: A transaction process-based approach for capturing service quality in online shopping. Journal of Business Research 59: 866875.

Beatty, S. - Smith, S. (1987): External search effort: An investigation across several product categories. Journal of Consumer Research 14: 83-95.

Bellman, S. - Lohse, G. L. - Johnson, E. J. (1999): Predictors of Online Buying Behavior. Communications of the ACM 42: 32-38.

Bentler, P. M. (1990): Comparative fit indexes in structural models. Psychological Bulletin 107: 238246.

Bone, P. F. (1992): Determinants of word-of-mouth communications during product consumption. Advances in Consumer Research 19: 579-583.

Bone, P. F. (1995): Word-of-mouth effects on short-term and long-term product judgments. Journal of Business Research 32: 213-223.

Bowman, D. - Narayandas, D. (2001): Managing Customer-Initiated Contacts with Manufacturers: The Impact on Share of Category Requirements and Word-of-Mouth Behavior. Journal of Marketing Research 38: 281-297. 
Brown, J. J. - Reingen, P. H. (1987): Social ties and word-of-mouth referral behaviour. Journal of Consumer Research 14(3): 350-362.

Carlson, J. - O'Cass, A. (2010): Exploring the relationships between e-service quality, satisfaction, attitudes and behaviours in content-driven e-service web sites. Journal of Services Marketing 24: $112-127$.

Carmines, E. G. - McIver, J. P. (1981): Analyzing models with unobserved variables: analysis of covariance structures. In: Bohnstedt, G. W. - Borgatta, E. F. (eds): Social measurement: current issues. Beverly Hill, CA: Sage, pp. 65-115.

Chang, H. H. - Wang, Y-H. - Yang, W-Y. (2009): The impact of e-service quality, customer satisfaction and loyalty on e-marketing: Moderating effect of perceived value. Total Quality Management \& Business Excellence 20(4): 423-443.

Cheung, C. M. K. - Thadani, D. R. (2012): The impact of electronic word-of-mouth communication: A literature analysis and integrative model. Decision Support Systems 54: 461-470.

Cheung, M. Y. - Luo, C. - Sia, C. L. - Chen, H. (2009): Credibility of Electronic Word-of-Mouth: Informational and Normative Determinants of On-line Consumer Recommendations. International Journal of Electronic Commerce 13(4): 9-38.

Christodoulides, G. - Michaelidou, N. (2011): Shopping motives as antecedents of e-satisfaction and e-loyalty. Journal of Marketing Management 27: 181-197.

Chu, S. C. - Kim, Y. (2011): Determinants of consumer engagement in electronic word-of-mouth (eWOM) in social networking sites. International Journal of Advertising 30(1): 47-75.

Chu, S.C. - Kamal, S. (2008): The effect of perceived blogger credibility and argument quality on message elaboration and brand attitudes: an exploratory study. Journal of Interactive Advertising $8(2): 26-37$

Dellarocas, C. (2003): The digitization of word-of-mouth: promise and challenge of online feedback mechanisms. Management Science 49(10): 1407-1424.

Dick, A. S. - Basu, K. (1994): Customer Loyalty: Toward an Integrated Conceptual Framework. Journal of the Academy of Marketing Science 22: 99-113.

Engel, J. F. - Blackwell, R. D. - Minniard, P. W. (1990): Consumer Behavior, $6^{\text {th }}$ ed. Chicago.

Engel, J. E. - Kegerreis, R. J. - Blackwell, R. D. (1969): Word-of-mouth communications by the innovator. Journal of Marketing 33: 15-19.

Eurostat (2013) Statistics. http://epp.eurostat.ec.europa.eu/portal/page/portal/statistics, accessed 24 September 2016.

Feick, L. F. - Price, L. L. (1987): The Market Maven: A Diffuser of Marketplace Information. Journal of Marketing 51: 83-97.

Flynn, L. R. - Goldsmith, R. E. - Eastman, J. K. (1996): Opinion leaders and opinion seekers: Two new measurement scales. Journal of the Academy of Marketing Science 24(2): 137-147. 
Fornell, C. - Larcker, D. F. (1981): Structural equation models with unobservable variables and measurement error: Algebra and statistics. Journal of Marketing Research 18(3): 382-388.

Fuse, D. - Punj, G. - Stewart, D. W. (1984): A typology of individual search strategies among purchasers of new automobiles. Journal of Consumer Research 10: 417-431.

GFK (2014): Online vásárlás: a jó árak és a szélesebb választék miatt népszerüek hazánkban a külföldi webshopok [Online shopping: Foreign web retailers are popular due to good prices and wider choice], Press release, http://www.gfk.com/hu/news-and-events/press-room/pressreleases/lapok/online-vasarlas-a-jo-arak-es-a-szelesebb-valasztek-miatt-nepszeruek-hazankban-akulfoldi-webshopok.aspx, accessed 24 September 2016.

Gladwell, M. (2000): The Tipping Point: How Little Things Can Make a Big Difference. Little, Brown and Company

Hair, J. F. - Anderson, R. E. - Tatham, R. L. - Black, W. C. (1992): Multivariate data analysis with readings. New York: Macmillan.

Hair, J. F. - Black, W. C. - Babin, B. J. - Anderson, R. E. - Tatham, R. L. (2010): Multivariate data analysis (vol. 5), New York: Pearson Prentice Hall.

Hennig-Thurau, T. - Gwinner, K. P. - Walsh, G. - Gremler, D. D. (2004): Electronic word-of-mouth via consumer-opinion platforms: What motivates consumers to articulate themselves on the internet? Journal of Interactive Marketing 18(1): 38-52.

Herr, P. M. - Kardes, F. R. - Kim, John (1991): Effects of word-of-mouth and product attribute information on persuasion: An accessibility-diagnosticity perspective. Journal of Consumer Research 17(4): 454-462.

Hill, D. J. (1986): Satisfaction and consumer services. Advances in Consumer Research 13: 311-315.

Hofmeister-Tóth, Á. (2008): A fogyasztói magatartás alapjai: Vásárlási döntés, fogyasztási minták, életstílus [Basics of Consumer Behaviour]. Budapest: Aula Kiadó.

Homburg, C. - Baumgartner, H. (1996): Applications of structural equation modeling in marketing and consumer research: A review. International Journal of Research in Marketing 13: 139-161.

Hu, L.-T. - Bentler, P. M. (1999): Cutoff criteria for fit indexes in covariance structure analysis: Conventional criteria versus new alternatives. Structural Equation Modeling: A Multidisciplinary Journal 6: 1-55.

Hung, K. H. - Li, S. Y. (2007): The influence of eWOM on virtual consumer communities: social capital, consumer learning, and behavioral outcomes. Journal of Advertising Research 47(4): 485-495.

Johnson, M. D. - Fornell, C. (1991): A Framework for Comparing Customer Satisfaction across Individuals and Product Categories. Journal of Economic Psychology 12: 267-286.

Karakaya, F. - Barnes, N. G. (2010): Impact of online reviews of customer care experience on brand or company selection. Journal of Consumer Marketing 27(5): 447-457. 
Kenesei, Z. - Kolos, K. (2007): Szolgáltatásmarketing és -menedzsment [Service marketing and management]. Budapest: Alinea Kiadó.

King, C. W. - Summer, J. O. (1970): Overlap of opinion leadership across product categories. Journal of Marketing Research 7(1): 43-50.

Lazarsfeld, P. F. - Berelson, B. R. - Gaudet, H. (1984): The People's Choice. New York: Columbia University Press.

Lohse, G. L. - Bellman, S. (2000): Consumer buying behavior on the Internet: Findings from panel data. Journal of Interactive Marketing 14: 15-29.

Marsh, H. W. - Hocevar, D. (1985): Application of confirmatory factor analysis to the study of selfconcept: first and higher-order factor models and their invariance across groups. Psychological Bulletin 97: 562-582.

McKnight, D. H. - Kacmar, C. (2006): Factors of information credibility for an Internet advice site. In: Sprague, R. H. Jr. (ed.): Proceedings of the 39th Hawaii International Conference on System Sciences. Los Alamitos, CA: IEEE Computer Society Press.

Minocha, S. - Dawson, L. H. - Blandford, A. - Millard, N. (2005): Providing value to customer in ecommerce environments: the customer's perspective. Contemporary research in E-Marketing 2: 119-146.

Modahl, M. (2000): Now or Never: How Companies Must Change Today to Win the Battle for Internet Consumers. CMA Management 74: 6.

Montoya-Weiss, M. M. - Voss, G. B. - Grewal, D. (2000): Bricks to clicks: what drives consumer use of the internet in a multichannel retail environment? AMA Winter Educators' Conference Proceedings, pp. 347.

Murakami, K. - Natori, S. (2013): New Customer Management Technique: CRM by „RFM+I” Analysis. NRI Papers 186: 1-13.

Myers, J. H. - Robertson, T. S. (1972): Dimensions of Opinion Leadership. Journal of Marketing Research 9: 41-46.

Norman, A. T. - Russell, C. A. (2006): The pass-along effect: investigating word-of-mouth effects on online survey procedures. Journal of Computer-Mediated Communication 11(4): 1085-1103

Novak, T. P. - Hoffman, D. L. - Yiu-Fai Yung (2000): Measuring the Customer Experience in Online Environments: A Structural Modeling Approach. Marketing Science 19: 22.

Nunnaly, J. C. - Bernstein, I. H. (1994): Psychometric Theory. New York: McGraw-Hill.

Oliver, R. L. (1980): A Cognitive Model of the Antecedents and Consequences of Satisfaction Decisions. Journal of Marketing Research 17: 460-469.

Parasuraman, A. (2000): Technology Readiness Index (TRI): A Multiple-Item Scale to Measure Readiness to Embrace New Technologies. Journal of Service Research 2: 307. 
Park, D. - Kim, S. (2008): The effects of consumer knowledge on message processing of electronic word-of-mouth via online consumer reviews. Electronic Commerce Research and Applications 7(4): 399-410.

Reynolds, F. D. - Darden, W. R. (1971): Mutually Adaptive Effects of Interpersonal Communication. Journal of Marketing Research 8: 449-454.

Rogers, E. M. (2003): Diffusion of Innovations. New York: Free Press.

Sousa, R. - Voss, C.A. (2006): Service Quality in Multichannel Services Employing Virtual Channels. Journal of Service Research 8: 356-371.

Steffes, E. M. - Burgee, L. E. (2009): Social ties and online word of mouth. Internet Research 19(1): $42-59$.

Sun, T. - Seounmi, Y. - Guohua, W. - Mana, K. (2006): Online Word-of-Mouth (or Mouse): An exploration of Its Antecedents and Consequences. Journal of Computer-Mediated Communication 11: 1104-1127.

Szabó, K. - Hámori, B. (2006): Információgazdaság: Digitális kapitalizmus vagy új gazdasági rendszer? [Information Economics: Digital Capitalism or New Economic System?]. Budapest: Akadémiai Kiadó.

Szymanski, D. M - Henard, D. H. (2001): Customer Satisfaction: A Meta-Analysis of the Empirical Evidence. Journal of the Academy of Marketing Science 29: 16 - 35.

Teimouri, M. - Yaghoubi, N. M - Kazemi, M. (2012): The Effect of Electronic Service Quality on Customers Behavioral Intentions. International Journal of Marketing Studies 4: 179 - 197.

Van Alstyne, M. - Brynjolfsson, E. (2005): Global Village or Cyber-Balkans? Modeling and Measuring the Integration of Electronic Communities. Management Science 51(6): 851-868.

Van den Bulte, C. - Lilien, G. L. (2001): Medical innovation revisited: Social contagion versus marketing effort. American Journal of Sociology 106(5): 1409-1435.

Wangenheim, F. - Bayón T. (2004): The effect of word of mouth on services switching: Measurement and moderating variables. European Journal of Marketing 38(9/10): 1173-1185.

Wolfinbarger, M. - Gilly, M. C (2003): eTailQ: dimensionalizing, measuring and predicting etail quality. Journal of Retailing 79: 183-198.

Wolfinbarger, M. - Gilly, M. C. (2002): comQ: Dimensionalizing, measuring and predicting quality of the e-tailing experience. Center for Research on Information Technology and Organization.

Zeithaml, V. A. - Parasuraman, A. - Malhotra, A. (2002): Service Quality Delivery Through Web Sites: A Critical Review of Extant Knowledge. Journal of the Academy of Marketing Science 30: $362-375$

Zhu, F. - Zhang, X. (2010): Impact of online consumer reviews on sales: the moderating role of product and consumer characteristics. Journal of Marketing 74(2): 133-148. 